\title{
El maestro Rowe y los orígenes de la reflexión antropológica*
}

Recibido: 16/11/2017

Aprobado: 01/12/2017

Fermin del Pino Díaz

Consejo Superior de Investigaciones Científicas, Madrid

< fermindelpino@gmail.com >>

\section{RESUMEN}

Rowe (1964) es, tal vez, quien sugirió antes que nadie — con un fino sentido del tiempo histórico- que el jesuita Acosta fue el escritor de Indias que establece primeramente una secuencia temporal en que diversas etapas de la evolución cultural se «suceden» unas a otras. La tipología presente en el proemio de su tratado misional (De Procuranda Indorum salute, 1588) se «historiza» solamente en su Historia de 1590, precisamente al toparse con las tradiciones mexicanas sobre su pasado por contraposición con los «chichimecas», que Acosta percibe como "paralelas» a las tradiciones incaicas sobre los «chunchos» de los Andes,

$\mathrm{Al}$ ańo siguiente publicará Rowe una reflexión general sobre «los orígenes renacentistas de la antropología» (American Anthropologist, 1965): lo que importaba de esta disciplina era haber destruido el etnocentrismo cristiano a la hora de contemplar otras culturas, $y$ eso por la admiración y traducción nueva de los humanistas italianos de los siglos xIV y xv hacia los textos y monunentos clásicos, producto de una cultura no cristiana. Yo encontré un filón interpretativo en estos dos artículos $(1964,1965)$ para construir un edificio antropológico al P. Acosta, afiliándolo a la corriente humanista más que confiando en sus datos etnográficos (la mayor parte prestados).

PALABRAS ClAVE: José de Acosta, Rowe, Historia de la Antropología, Teoría del progreso, Andes, Mesoamérica.

\section{Master Rowe and the origins of anthropological thinking}

\begin{abstract}
Rowe (1964) is, perhaps, who suggested before anyone - with a fine sense of historical time - that the Jesuit Acosta was the writer of Indias first establishing a temporal sequence in which some stages of cultural evolution 'succession' ones to others. The type present in the proem of his missionary treat ise (De Procuranda Indorum salute, 1588) is 'historized' only in his history of 1590 , precisely to the encounter with Mexican traditions about his past by contrast chichimecas, which Acosta perceived as 'parallel' to Inca traditions about the 'chunchos' of the Andes. In the following year published Rowe a general reflection on 'the Renaissance origins of Anthropology' (American Anthropologist, 1965): what mattered in this discipline was having destroyed ethnocentrism Christian to see other cultures, and that the admiration and new translation of the Italian humanists of the 14th and 15th centuries the texts and classic monunentos, product of a non-Christian culture. I found a reef interpretation in these two articles $(1964,1965)$ to construct a building anthropological P. Acosta, affiliating with the current humanist rather than trusting their ethnographic data (mostly borrowed).
\end{abstract}

KEYWORDS: Jose de Acosta, Rowe, History of Anthropology, Theory of Progresso, Andes, Mesoamerica. 
John H. Rowe, mi clásico

A sí le dedicaba yo -hace unos 15 ańosun trabajo que redacté sobre el humanismo y valor etnográfico del P. Acosta, para asociarme a tres jóvenes colegas que acababan de terminar su tesis doctoral sobre sendas figuras intelectuales del pasado (el dominico Francisco de Vitoria, el franciscano Bernardino Sahagún y el clérigo y letrado López Medel). ${ }^{1}$ Hoy quiero conservar este mismo 'motivo', aunque amplíe mi atención a varios de sus trabajos y centre mi atención a su producción teórica como historiador de la antropología.

Debo decir que mi interés en la obra del jesuita Acosta no era 'monográfico' y especializado en su figura al principio, como más tarde cuando he descubierto lo peculiar de su caso en la historia indigenista de la Compañía de Jesús; anteriormente, el ejemplo de Acosta no era para mí sino un hito en la historia general de la Antropología occidental, cuyo componente hispánico trataba yo de destacar. La circunstancia en que elegí como tesis doctoral el tema de las crónicas hispanas de Indias y la Antropología, a fines de los años $60,{ }^{2}$ era la de una renovación nacional de la disciplina acometida por obra de miembros de mi generacion, alumnos todos de algunos colegas mayores formados fuera de España o con profesores extranjeros (Julio Caro Baroja, Claudio Esteva Fabregat y Lisón Tolosana...). Mi inmersión previa en la historia intelectual colonial, de la mano de profesores americanistas como Pérez de Tudela (editor de las obras del P. Las Casas y Fernández de Oviedo) o José A. Maravall (reivindicador temprano de nuestro Renacimiento y su teoría del progreso) me condujo insensiblemente a plantear una reivindicación nacional de la disciplina antropológica, buscando hitos pasados en el terreno más estudiado, las Crónicas de Indias.

La estrategia consistió en repasar cuidadosamente las opiniones expresadas sobre el valor etnográfico de las crónicas de Indias en las principales 'historias nacionales de la disciplina», eligiendo en el extranjero

1 «Humanismo renacentista y orígenes de la Etnología: a propósito del P. Acosta, paradigma del humanismo antropológico», en Berta ARES, Jesús BUSTAMANTE, Francisco CASTILLA y Fermín DEL PINO (Eds.), Humanismo y visión del otro en la España moderna: cuatro estudios, Madrid, C. S. I. C., Biblioteca de Historia de América, 6, 1991, pp. 379-429.

2 «Historia de la antropología en España: Opiniones y proposiciones con relación a las crónicas americanas», Facultad de Ciencias Políticas y Sociología, Madrid, abril de 1975, 531 pp. Apenas mencionado el P. Acosta en la tesis, como comentario a la historiografía antropológica de Rowe, ha sido luego objeto de unos 30 trabajos míos a partir de 1978. cuatro paises con tradición propia como Francia, Inglaterra, Alemania y Estados Unidos. Me costó familiarizarme con las diferentes 'historias de la tribu', según países y escuelas, ayudándome de mi familiaridad bibliográfica dentro de la historia del americanismo, así como de la historiografía general de la ciencia (a la que me incorporé pronto como socio fundador de la Sociedad española de Historia de la ciencia en 1977, hace 40 años). De ahí saqué el convencimiento de que la historiografía antropológica estaba - al igual que la propia disciplina antropológica- particularmente desarrollada en los Estados Unidos (a nivel de congresos, manuales, tesis doctorales, revistas), como evidenciaba el magisterio indiscutido de George W. Stocking en Berkeley y Chicago. De todas las tradiciones nacionales, la americana se interesaba particularmente en las crónicas de Indias hispanas por razones nacionales, lo que me convenía mucho. Obviamente, existían a su vez diversas tradiciones regionales internas (Pensylvannia, Washington, Chicago, Columbia, Harvard, Berkeley, Texas...), ligada tanto a la historia universitaria y de sus profesores, como a la presencia hispana en el pasado: de ahí el enorme peso de los estados del Suroeste, que empleaban la documentación hispana para su afirmación 'regional' frente a al Este.

A esta oposición entre la costa este y la del oeste pertenece el interesante despliegue de la labor del suizo Adolph F. Bandelier, cuya correspondencia doble estudié (con el abogado de Rochester, Henry L. Morgan, y con el historiador hispano-mexicano Joaquín G. Icazbalceta, que pasó su infancia en Cádiz) para entender los misterios y vaivenes del hispanismo norteamericano. Las historias de la costa este seguían la tradición europea (particularmente franco-británica) de elevar la Ilustración al nivel de 'período fundacional' de la disciplina, mientras que al oeste (California, Nuevo México, Texas...) se insistía en el valor fundacional del siglo de oro hispano. Cada país reivindica como fundacional aquel período de su pasado que le distingue frente a los otros, donde halla más presencia propia. ${ }^{3}$ Frente al esplendor ilustrado de la American Philosophical Society, de Filadelphia, las jóvenes universidades del oeste se remontan al pasado

3 De un modo parecido, pude comprobar la importancia concedida en la megalópolis moderna de Sao Paulo a la antigua fundación jesuita, cuya casa fundacional era respetada arquitectónicamente por los rascacielos cercanos, frente al modernismo estético de Rio de Janeiro. Tal vez también por ese motivo 'regionalista' Sao Paulo mima sus recuerdos 'imperiales' del emperador portugués, conservando bien cuidados sus monumentos decimonónicos. 
hispánico, a las crónicas del descubrimiento y al Renacimiento (de ahí la collección Bancroft de Berkeley y la mexicanista de Texas, la escuela historiografica de Bolton, la labor etnohistórica de Borah y Simpson, etc.). Aparte de ello, la Universidad de Berkeley dispuso en los años 60 del magisterio histórico-científico del físico Thomas Kuhn, que se interesaba además en las ciencias humanas (particularmente en la psicología), y ello benefició enormemente a la antropología, que pudo conformar el proyecto más serio de la historiografía mundial en manos del historiador profesional Stocking (antes de su marcha a Chicago), del arqueólogo Rowe o del lingüista Dell Hymes.

\section{El caso particular del P. Acosta}

Aparte del magisterio final de Stocking, y sus reglas metodológicas contra el presentismo tribal de la historiografía antropológica, pude en esta indagación doctoral llegar a conocer con detalle la rica producción internacional acerca de la antropología americanista del pasado, de origen hispano. Es así cómo al final de mi tesis, allá por el curso 72/73, descubro dos textos dedicados al siglo Xvi elaborados en California, ambos de 1964: el libro de la historiadora de las ideas Margareth T. Hogden sobre la antropología del s. $\mathrm{XVI},{ }^{4}$ y el artículo de Rowe de ese mismo año sobre la etnografía europea del s. XVI, en una prestigiosa revista de estudiantes de Berkeley. ${ }^{5}$ De ellos fui alertado por

4 Early Anthropology in the Sixteenth and Seventeenth Centuries, Univ. of California Press, San Marino, 1964.

5 "Ethnography and Ethnology in the Sixteenth Century», en Kroeber Anthopological Society Papers (Berkeley, Calif.), 30: 1-15 (1964). Poco anteriores o posteriores son otros dos artículos suyos: «Sixteenth and Seventeenth Century Grammars», en Dell HYMES (Ed.) Studies in the History of Linguistic. Traditions and Paradigms. Bloomington/ London: Indiana Univ. Press, 1974. «The Renaissance Foundations of Anthropology" American Anthropologist, 1: 1-19 (1965). Este ha sido reimpreso en R. Darnell (ed.) Readings in the History of Anthropology. Nueva York, Harper and Row Pub., 1974. Originalmente fue leído este ensayo en 1963 en la séptima asamblea anual de la Kroeber Anthropological Society, de Berkeley (California). Descubrí este artículo modélico en 1974, a punto de concluir mi tesis doctoral, pero sirvió para vertebrarla. La apliqué tempranamente en Fermín DEL PINO «Canarias y América en la historia de la Etnología primigenia: usando una hipótesis». Revista de Indias, vol. 145-146: pp. 99-156 (1976). Asimismo en otros tres estudios: "Contribución del padre Acosta a la constitución de la etnología. Su evolucionismo", Revista de Indias, no 153-4, pp. 507-546 (julio-diciembre, 1978); en "Culturas clásicas y americanas en la obra del Padre Acosta», pp. 327-362 del tomo I, en F. DE SOLANO y F. DEL PINO: América y la España del siglo XVI. Madrid: CSIC (1982), y finalmente en «Humanismo clasicista mediterráneo y concepción antropológica del mundo: el caso de los jesuitas», Revista Hispania,192: 29-50 (1996). el manualito del conocido hispanista John H. Elliott (1970, en traducción de 1972). ${ }^{6}$ Tal vez no se haya hecho justicia en el gremio americanista a este texto de revisión bibliográfica de Elliott, que mereció la pronta traducción española, y que estuvo acompañado de algún otro artículo coetáneo sobre el impacto limitado del hecho americano en la conciencia europea ${ }^{7}$.

Supongo que se imaginan la emoción con que descubrí estos dos textos, que al fin se hacían cuestión explícita del objeto de mi investigación doctoral, entonces a punto de concluirse. El mérito principal es que se trataba de un ambicioso 'estado de la cuestión', llevado a cabo con intenciones divulgadoras por un historiador inglés experto en la historia moderna de España, que quería aplicar su enorme background historiográfico a una materia periférica en su estudio previo, hacia la que quería inclinarse con toda su prudencia comparatista. ${ }^{8}$ Una prueba de su interés histórico-antropológico es su atención a esta misma bibliografía, y la dirección intelectual del entonces joven historiador de las ideas Anthony Pagden para producir en Princeton su magistral The fall of Natural man... (Cambridge, 1982), ${ }^{9}$ que es un despliegue considerable del cap. II del libro de Elliott, en 1970, donde se reconoce la utilidad del articulo de Rowe (1964). Aunque luego el joven historiador no desarrolló en ese libro el punto de vista a favor del Humanismo, por lo cual ni siquiera cita a Rowe.

6 ELLIOTT, John H., The Old and the New World. 1492-1650, Cambridge U. Press, 1970, con traducción espańola de 1972 (y numerosas reimpresiones): El Nuevo Mundo y el Viejo. Alianza Editorial, Madrid. Creo que la primera noticia del interés especial del profesor Elliott por la temprana etnografía colonial hispanoamericana la recibí de labios del lascasista Lewis Hanke, de visita frecuente en Espańa. Mi primer interés proto-antropológico se dirigía a mi paisano Las Casas, guiado por las propuestas de Hanke y de otro lascasiano ilustre, mi primer director de tesis, Pérez de Tudela.

7 ELLIOTT, John H., «The discovery of America and the discovery of man», Proceedings of the British Academy, 1972, reeditado en Spain and its world, 1500-1700. Selected Essays, 1989. Asimismo en «Renaissance Europe and America: A blumted impact? En Fredi CHIAPELLI (Ed.) First Images of America. The impact of the New Worl on the Old. University of California Prees, Berkeley, vol. 1., 1975, pp. 11-23.Ver sobre el eco americanista de este hispanista la semblanza del historiador sevillano Ramón M. Serrera, «Sir John H. Elliott y el Nuevo Mundo» en Boletín de la R. Academia Sevillana de Buenas Letras, 39: 291-311.

8 Hasta mucho después no ha salido el resultado de su larga indagación comparatista entre la Espańa imperial y el imperio británico, Cf. Imperios del mundo atlántico, Taurus, 2006 (en simultánea edición inglesa). En ello vuelve a emular al profesor Lewis Hanke, que lo ensayó igualmente sobre el campo americano.

9 PAGDEN, Anthony. La caida del hombre natural. El indio americano y los orígenes de la etnología comparativa. Madrid: Alianza Editorial, 1988. (Traducida de la más amplia 2a edición de la Cambridge U.P., de 1986). 
Mi entusiasmo me llevó a contratar la traducción del denso libro de M.T. Hodgen, con ayuda de una anglohablante, alumna mia de antropología, tarea en la que llegué hasta la mitad del libro: justamente hasta percibir su íntima debilidad argumental y de conocimiento. ${ }^{10}$ Tuve que soportar a comienzo de los 70 la tediosa lectura -por minuciosa en su ejemplificación, anticuada en su argumentación, y antipática hacia los autores estudiados de los siglos supuestamente preantropológicos- del conocido manual de Hodgen (1964) hasta descubrir la maravillosa brevedad, sistemática coherencia, y empática comprensión del pasado de textos como los de Rowe.Tanto el viejo texto de Hodgen como los actuales estudios históricos postmodernos - que niegan la capacidad temprana de comprender las otras culturas extraeuropeas- se parecen mucho en desconfiar de la posibilidad de un conocimiento antropológico, stricto sensu, sin ningún prejuicio sobre el otro. Siendo tan escasos en el pasado los ejemplos de textos no-etnocéntricos, prefieren dedicar su tiempo a los que abundan y a los que no siempre nos enseñan algo seguro (ése era el papel de Sebastian Muenster y Joham Boemus en la estrategia de la profesora Hodgen), a los que dedicó la atención principal del libro, para mostrar el poco interés de la etnografía del s. XVI. No me extrańa la diferente actitud hacia ambos (Rowe y Hodgen) de especialistas como George W. Stocking, guía de muchos historiadores de la antropología. ${ }^{11}$

El trabajo de Rowe a favor del P. Acosta logró ser escuchado, y ése fue el primer fruto para mí. En nuestros días se le ha reconocido al jesuita castellano ese mérito especial por parte del profesor Elliott, señalándola como la obra "que culminó principalmente el proceso de integrar el mundo americano en el contexto general del pensamiento europeo» (1972: 53). Y su discípulo A. Pagden dijo asimismo -en su conocido libro, que ya dedicaba al P. Acosta uno de los capítulos más extensos- que «era quizá la única obra que los contemporáneos reconocieron como

\footnotetext{
10 La tarea traductora (a medias con Guadalupe Rubio) me llevó varios meses de arduo trabajo hasta la mitad del libro (incluyendo los 6 primeros capítulos, hacia la pág. 300). El inglés del período temprano moderno que nos citaba la autora nos creaba contantes problemas de interpretación. Gran parte del aprendizaje antropológico de esos ańos en Espańa se relacionaba con la labor editorial de las traducciones: en 1971 se publicó mi traducción del Manuel d'Ethnographie de Marcel Mauss (1947, Payot), contemporáneo de mi primer trimestre trabajo de campo en Madre de Dios (Perú), sobre la migración altiplánica.

11 He seguido los comentarios de Stocking a este libro negativo en Isis,
} 55-4: 454-455, 1964. innovadora» (1988: 291). Con lo cual, parece que los lectores aceptaban unánimemente la reclamación del autor, acerca de su novedad, en el prólogo a su edición príncipe sevillana de 1590:

Del Nuevo Mundo e Indias occidentales han escrito muchos autores diversos libros y relaciones, en que dan noticia de las cosas nuevas y extrañas que en aquellas partes se han descubierto [...] mas hasta ahora no he visto [...] libro cuyo argumento sea los hechos e historia de los mismos indios, antiguos y naturales habitadores del Nuevo Orbe (...) por no saber su lengua (cursivas mías).

De hecho, yo mismo he dedicado frecuentemente mi atención a este autor como 'maitre à penser' — que dicen los franceses de sus intelectuales-; pero no tratándolo solo como evolucionista sino más bien como humanista coherente, como un jesuita de primera hora a quien su formación clásica le llevó a comprender mejor a los pueblos paganos contemporáneos (India oriental y occidental). Por otra parte, continúo hoy respecto al profesor Rowe con la misma actitud críticoapologética (que diría un ilustrado peruano) ${ }^{12}$ de entonces. Es decir, creo que ha sido un componente esencial de mi trabajo histórico en apología de fuentes hispanas, pero considero críticamente que el propio autor no extraía toda la consecuencia que se derivaba de sus originales planteamientos teóricos y metodológicos. Hace tiempo, releyendo un pasaje de la Historia de la Etnología del maestro Robert H. Lowie - con el que mi maestro Rowe guardaba tantas concordancias y concomitancias, ambos como alumnos devotos del maestro alemán Franz Boas- me sentí bien reflejado en relación con mis sentimientos hacia su obra. Ante un auditorio americanista no es necesario recordar el papel protagonista de Boas en la antropología mundial, ni el de su alumno Lowie como clave en la formación intelectual de otros americanistas fundamentales como Metraux o Lévi-Strauss: el libro que comento, a su vez, es también ejemplar en la constitución disciplinar de la historia de la Etnología. Algunos críticos dicen que muestra bien la dependencia de Lowie con Boas: lo cierto es que justamente el capítulo dedicado a Boas se enfrenta al final con la paradoja de que Boas no ha sido reconocido tan maestro disciplinar como debiera,

12 José Eusebio Llano Zapata, Memorias histórico-físicas, critico-apologéticas de la América meridional, Lima, IFEA y Fondo editorial de la PUCP, 2005. Ricardo Ramírez et alii (editores). Subrayado mío. 
y proponía su discípulo que se debía a su alergia a plantear generalizaciones y síntesis de su propio trabajo:

Es esta marcada aversión a sistematizar lo que causa desesperación e incomprensión a muchos de sus lectores... Boas, al igual que Tylor, al dejar de definir la esfera de las 'leyes generales' en contraste con las de la historia específica, nos lleva a la incertidumbre metodológica» (1946, pp. 187 y190).

Como digo, mi interpretación de Rowe puede ser entendida mejor con este precedente, que creo razonable dadas las concomitancias de nuestro autor con Boas (que él expresó en alguna ocasión). Lo que desarrollé primeramente en mi ensayo de 1992 es su aparente contradicción entre los dos artículos sucesivos que publicó en 1964 y 1965: en uno de los cuales se mostraba la poca importancia en la disciplina antropológica de las teorías o puntos de vista, y en el otro justamente se enfatizaba que lo que desencadenó el origen disciplinar fue un nuevo punto de vista, una teoría. Efectivamente en el primero de ellos, comienza planteando su tesis para ambos siglos:

(...) the beginnings of anthropology are to be sought in the Renaissance movement in Italy in the fifteenth century, and specifically in Renaissance archaeology and related activities. What we find in the fif'teenth century, however, is little more than a point of view which made anthropological observation possible, the beginings of an interest in differences among men. In the sixteenth century there was a great expansion of anthropological observation, and we find the first attempts to classify and interpret anthropological data... // The scholars of the Renaissance movement turned to Classical antiquity for inspiration, with the conviction that the ancients were superior to the moderns in such important fields as literature, art, philosophy, political organization, the art of war and natural science. Respect for antiquity undermined the ethnocentric self-assurance which had previously characterized Europeans and thus prepared some of them to be more observant and more tolerant of contemporary cultural differences. (1964: 1 y 7 ).

El punto de vista proporcionado por el Renacimiento que hizo posible la observación de las diferencias culturales entre los grupos humanos (característica de la visión antropológica) fue la crítica del punto de vista previo, el etnocentrismo, que enfatizaba el valor de las semejanzas culturales. Pero no solo proporcionó el modelo clásico una valoración de las culturas no cristianas, sino que nos mostró el modo de describir estas diferencias, en términos que permitiese una posterior comparación e interpretacion. Así lo planteará al comienzo de su otro trabajo de 1965 sobre los humanistas italianos de los s. Xv y Xv:

Renaissance studies of Classical antiquity not only stimulated a general interest in differences among men, they also provided models for describing such differences. When the problem of describing contemporary non-Western cultures arose, there were Renaissance studies of Roman customs and institutions to serve as precedents. Similarly, Renaissance grammars and dictionaries of Classical Latin and Greek became models for the description of spoken languages in all parts of the world, and the study of the ancient monuments of Italy and Greece became the basis for archaeological reporting elsewhere. The beginnings of physical anthropology were delayed, because the study of Classical antiquity in this case offered little precedent. (1965: 1)

En realidad, la etnografía comparada propiamente dicha nace al siglo siguiente, pero con muchas limitaciones:

the primary comparison is between sixteenth century European customs and institutions and those recorded in Classical literature. The contemporary ethnographic examples cited represent only a fraction of those on which there was published information, and they are not central to the argument. With all their limitations, however, these studies constitute the beginnings of an attempt to determine the range of variation of human behavior (1964: 4).

Yo creo que Rowe exageró el 'limitado valor' de la etnografía para la Antropología del s. XVI, en su primer artículo de 1964. Digo esto porque tampoco se puede hablar propiamente de una etnografía en el s. Xvi (al igual que en el Xv), sino de unos conocimientos numerosos sobre el hombre no cristiano (fundamentalmente americano), en gran parte necesarios para el gobierno colonial, económico o religioso, que fueron posibles porque se había superado el prejuicio previo — producto del etnocentrismo anterior- de la inferioridad cutural en las sociedades no cristianas. Es curioso que Rowe en 1965 subraye el prejuicio occidental ante las diferencias culturales de otras culturas antes del Renacimiento (no solo de 
parte de los cristianos sino asimismo de los griegos y romanos) pero que, al mismo tiempo, enfatice la 'tolerancia intercultural' hacia las otras civilizaciones en sociedades no occidentales (como la persa, señalando el relativismo del rey Darío, o el poliglotismo de sucesores como Mithrídates o Ptolomeo IV, autor de decretos en varias lenguas como la piedra Rosetta), de donde habría nacido el interés intercultural por los persas y escitas de Heródoto, nacido en Halicarnaso: en la frontera del imperio persa. Curiosamente, aunque no se subraye, la posición clasicista de Rowe esconde una crítica hacia las historias coetáneas de la ciencia, que se remontan al pasado clásico sin la suficiente consciencia de la contribución revolucionaria del Renacimiento: si bien los humanistas se inspiraron en el pasado clásico, ello fue a costa de una rebelión contra su pasado inmediato medieval (clasicista también a su manera, pero sin consciencia de discontinuidad con el pasado, sin perspectiva sobre la diferencia real que les separaba) y también a costa de una superación del venerado pasado clásico, con logros presentes superiores.

Tras este precedente antiguo y externo sobre Occidente, la superación moderna del etnocentrismo fue en gran parte, a su vez, efecto de las comparaciones realizadas con las sociedades antiguas de Europa por los humanistas del s. Xv; es evidente asimismo en el s. Xvi la intención de dar uso práctico a estos conocimientos pedidos a los funcionarios o viajeros (como destaca Rowe), pero creemos que su origen real es tanto esta necesidad práctica como su contexto mental, que lo hizo posible: la formación clasicista de los administradores que la acometieron, tanto eclesiásticos como letrados. Si bien en el ensayo de 1965 enfatiza Rowe la importancia del 'punto de vista' humanista, en el otro ensayo anterior sobre la Etnología del s. XVI insiste en oponer dos tradiciones 'interpretativas' de las diferencias culturales entre las sociedades: una nutriéndose solamente de las culturas del Viejo Mundo, antiguas y modernas (la filosofía social', en que incluye a escritores notables: antiguos como Aristóteles y Platón, o modernos al estilo de Jean Bodin, Montaigne, Louis de Roy, Cristóbal de Villalón...) y, por otro lado, la teoría etnológica (en que ubica principalmente al P. Acosta, aunque contaminado parcialmente de la filosofía social). La gran teoría de la filosofía social (que Rowe combate como no etnográfica) es la 'teoría del progreso', que justamente es localizada en el propio jesuita, tanto en su tratado misional como en su Historia indiana, donde llega Rowe a postular hechos que no son del todo ciertos (como que Acosta no aplicó esta teoría sino a las sociedades americanas: "he did not suggest that it applied to the Old World as well», 1964: 9), y sobre todo:

«Acosta was apparently the first writer who attempted to formulate a body of ethnological theory distinct from the tradition of social philosophy. He outlined a hierarchical classification of non-European peoples based on the categories of European popular usage (...) the categories of the classification did not arise from detailed comparisons of ethnographic data but were derived from European popular conceptions into which Acosta fitted the meager data that he had. The idea of progress similarly was not based on the study of a continuous historical and archaeological record of the past but on limited historical data which were selected to fit the theory, on speculation, and on ethnocentric value judgments» (1964: 9).

En todos estos trabajos se enfatiza el peso de la tradición clásica, es verdad que de la mano siempre de la cristiana, a la hora de modelar las respuestas culturales al impacto con el Nuevo Mundo. En general, tanto para Rowe (1965) como para Elliott (1970), la tradición clásica y cristiana se enfocan positivamente como un mero planteamiento teórico inicial, que luego es corregido por la realidad de los hechos y la experiencia moderna. Desde el principio se advierte, en tono casi postmodernista, que estamos hablando de «esquemas» o visiones y no de realidades, ya que esta dificultad en 'asir la realidad' americana la tuvieron entonces incluso los más sensibles misioneros o humanistas, como hoy la tiene un antropólogo corriente, desgraciadamente. A pesar de todas las renuencias europeas ante las novedades del hecho americano, el balance final era positivo en términos de adaptación sociocultural gracias a la riqueza plural de la propia tradición cultural:

"Rather than pointing Europe in totally new directions, the discovery of America emphasized and strengthened certain elements in European civilization at the expense of others. This happened because the Judeo-Christian and classical traditions were themselves so rich and varied that they made it possible both to interpret and absorb a substantial part of what America had to offer without provoking a seismic shock in the European system» (Elliott, 1975: 17). 
Ahora bien, este énfasis en el carácter limitado del efecto aperturista producido por América, y en la parcial intermediación clásico-cristiana para evitar el shock, no le impide poco más adelante centrar su atención en un problema más propiamente intelectual, donde la tradición clásica ejerce ya un papel menos ambiguamente positivo en el camino de la comprensión intercultural, propuesta en 1965 por Rowe:

The classical tradition, both as Christianized by the scholastics and revitalized by the humanist, played a decisive part in facilitating European acceptance of the peoples of America as members of viable and valid societies (...) Even if others looked upon the Indians as closer to beasts than to men, European still possessed within their own cultural tradition the mental equipment necessary for perceiving and recognizing alien societies. As trained by Renaissance humanism, it made them specialy well suited to deal with the cultural consequences of overseas discovery. Here, after all, was a generation acutely conscious of a civilization that was not its own -that of Greek and Roman antiquity- and one wich was now far removed in time. Its newly adquired sense of temporal perspective must have helped it to come to terms also with civilizations far removed in space.

[...] If classical antiquity provided Europeans with an alternative image -the existence of which alone makes it possible for develop some sense of perspective- it also game them the basis tools of inquiry for the investigation of other lands and peoples» (Elliott, 1975: 18) ${ }^{13}$.

Naturalmente, tales ideas acerca del conocimiento del otro va especificando cada vez de quién la toma, en lo cual es meticuloso el profesor Elliott, y es raro encontrar un único precedente principal claro; pero, si hay que buscar un texto previo a sus ideas dentro de la bibliografía histórico-antropológica, no cabe duda que este puesto lo tiene Rowe. El propio autor lo reconoce en la nota 3 del cap. II de su El viejo Mundo y el Nuevo..., sobre «El proceso de asimilación», donde se trata el tema que nos ocupa: «Este folleto [Rowe, 1964] me ha sido muy útil para la elaboración de algunos de los aspectos contenidos en este capítulo». Desgraciadamente, este artículo del profesor Rowe sobre la etnología mundial durante el s. Xvi apoyaba el temor de Elliott sobre la falta de «experiencia» etnográfica de muchos

13 Compárese con la cita que tomamos de Rowe, 1965, de la p.1, es decir al comienzo de su articulo: tras lo cual no se entiende que Elliott no la haya utilizado a su favor en 1970, y trabajos subsiguientes. de los filósofos europeos como Montaigne, Le Roy, Bodin..., alimentados solamente de su conocimiento de las sociedades del Viejo Mundo, y especialmente de la antigüedad, y con enormes prejuicios sobre salvajes, paganos y bárbaros. La excepción principal a estos defectos la encuentra Rowe (1964) en algunos informes misionales, y especialmente en la Historia natural y moral de las Indias del jesuita José de Acosta, que acometió una historia geográfica y natural del Nuevo Mundo, además de una etnografía cuidadosa del antiguo México y Perú.

Curiosamente, el esquema evolutivo de Acosta que acompaña esta minuciosa descripción etnográfica - especialmente peruana y mexicana, cuyos ancestros habrían evolucionado hasta donde estaban en tiempos del autor, desde posiciones culturales parecidas a los otros pueblos menos evolucionados del presente en América - no le merece admiración a un arqueólogo como Rowe. Tal vez porque se trata de un polivalente incaista (especialista en campos variados como la etnohistoria, la lingüística y la arqueología), que estaba muy enfrentado a las conjeturas del evolucionismo multilineal imperante, por lo que más bien le merecen conmiseración contextual —en su tiempo temprano- y sirven como argumento de crítica a la poca sofisticación teórica de sus herederos actuales, desde una posición positivista y empírica. Así termina su breve ensayo:

Then, perhaps partly under the influence of the nascent theory of progress, he turned the part of his scheme which related to America into an evolutionary sequence (...) In the situation prevailing in the sixteenth century it can, perhaps, be argued that any ethnological theory was better than none, and if so Acosta deserves great credit for an original combination of ideas which became the foundation of an important intellectual tradition. It is hardly creditable to twentieth century anthropology, however, that the popular prejudices of the sixteenth century still form the framework in which many anthropologists try to handle the problems of variation and change (Rowe, 1964: 9, cursivas mías).

Si sólo se tuviese en cuenta este trabajo del profesor Rowe, el aprecio que realiza de Acosta resultaría algo contradictorio, cotejado con su valoración general del pasado clásico como desencadenante de una posición no-etnocéntrica; pues de Acosta ya veremos que destaca precisamente por su erudición de base clasicista, 
y gran parte de su esquema evolucionista está tomado precisamente de su inspiración aristotélica. En mi opinión lo que vale, para siempre, de la contribución de Rowe a la historia del pensamiento etnológico -campo en el cual también se considera relevante su contribución, por ejemplo, para gentes de criterio como Stocking, Hymes, o R. Darnell- es su excelente demostración sobre los «fundamentos renacentistas de la antropología», y no tanto por esta desconfianza típica suya sobre el evolucionismo y la teoría etnológica que lo sostiene. A ello precisamente (que apuntaba tímidamente en la cita que hemos tomado antes del prof. Elliott, para justificar el uso derivado en la argumentación del profesor Rowe) dedicó otro artículo al año siguiente, que ha obtenido una circulación más amplia dentro del gremio antropológico, mostrando con cierta rigurosidad que antes del Renacimiento no hubo propiamente antropología, ni en cantidad ni en calidad: porque los pocos antecedentes que pueden tenerse en cuenta realmente (Heródoto, Tácito, Megástenes de Hecatea, Estrabón, Plinio, Marco Polo, Piano Carpini y Rubruquis) no fueron valorados en su tiempo precisamente por su etnografía sino por sus fabulosas narraciones de aventuras: caso notable de Heródoto, analizado previamente por Momigliano (1960).

Todos estos autores clásicos constituyeron luego testimonios etno-históricos mejor valorados en el Renacimiento, que los volvió a publicar cuidadosa y masivamente con ayuda de la imprenta, y que además llenó de nuevas narraciones etnográficas el mercado de lecturas disponibles: en este ambiente es donde nacen la mayor parte de los primeros relatos etnográficos de finales del xv sobre África y América, generalmente a cargo de personajes italianos relacionados con el Renacimiento italiano (Cadamosto, Pietro Martire, Ramusio, Botero...). Tras este prólogo temporal dedicado al s. xv se explica mejor su otro trabajo anterior dedicado al s. Xvi (de 1964, que es el único conocido o citado por el profesor Elliott), del cual aquél era en realidad una introducción. ${ }^{14}$ En cualquier caso resulta sorprendente la proximidad temporal entre ambos ensayos, y la distancia de puntos de vista entre la cita subrayada anteriormente por nosotros (Elliott, 1975: 18) y la que da inicio al trabajo siguiente:

14 Ambos trabajos fueron objeto de una ponencia propia en la Sociedad Antropológica Krober, de Berkeley: el dedicado al s. XV en 1963 (no publicado entonces sino en 1965, fuera de California) y el de 1964, publicado ese año en las actas de esa sociedad californiana.
«It is the thesis of this paper that the anthropological tradition of interest in differences among men had its beginnings in the Italian Renaissance of the 14th and 15th centuries and specifically in Renaissance archaelogy. The first differences which were recognized as significant to a general understanding of mankind were the cultural and linguistic differences between Classical antiquity and what was then the present. Its was only after the beginnings of an archaelogical perspective had been established that the interest in differences was extended to contemporary contrast... Renaissance studies of Classical antiquity not only stimuled a general interest in differences among men, they also provided models for describing such differences» (Rowe, 1965: 1, cursivas mías).

El profesor Rowe (a quien llegué de la mano de J. H. Elliott, cuyo texto de 1970 obtuvo una excelente difusión castellana en 1972) ha logrado una enorme audiencia con este artículo de 1965, que ha merecido varias re-impresiones, entre ellas una muy conocida de Regna D. Darnel (1974). Para mí, como para muchos colegas que intentábamos orientarnos en una selva de precursores, y en medio de varias y contradictorias posturas historiográficas, su artículo significó una luz, al final de un túnel: no es fácil hallar un criterio convincente - $\tan$ íntimamente coherente- en un campo tan sometido a presiones del presente como la historia de una disciplina en crisis, tal como fue la antropología en los años 60 (Del Pino, 1976). La Universidad de Berkeley debió contribuir a la excelencia académica de este trabajo: el propio Rowe (1965) reconoce en notas el aporte de varios de sus profesores, y se refiere de modo especial a Momigliano, cuyas «Conferencias Sather» de 1962 en Berkeley, aún inéditas entonces, habían sido el punto de partida para su reflexión en contra de la continuidad de la estela antropológica asumida generalmente por el gremio, desde el presente hasta la obra de Heródoto.

Naturalmente que Rowe no es el inventor absoluto de ese punto de vista, del cual he podido hallar algunos precedentes más o menos antiguos. ${ }^{15}$ Pero, para mí y

15 Me refiero especialmente a Claude Lévi-Strauss, tan insistente en sus referencias al pasado clásico (Hesíodo, Ovidio, Lucrecio...) en sus homenajes a precursores propios (Durkheim, Mauss...), que dedicó un artículo defendiendo la validez de los estudios clásicos para la formación de los estudiantes en su trato con otras culturas, en 1956 ("Les trois humanismes», recogido en su segunda antología de Antropología estructural): se lograba con ellos «situar su propia cultura en perspectiva, confrontando las concepciones contemporáneas con las de otros tiempos y lugares», puesto que «que ninguna civilización 
para muchos otros (si bien no todos lo reconocen), ha sido Rowe su difusor actual más eficaz y su analista más sistemático. El aprecio de la 'ruptura epistemológica' que trajo el Humanismo no es solamente una erudita indagación en los lejanos orígenes etnológicos, es útil también para introducir en la historia etnológica una verosímil solución de continuidad, para hacer coincidir sus orígenes con la cualidad considerada hoy definitoria, disciplinarmente: la ruptura del etnocentrismo. Al acentuar este interés cristiano por el pasado, no cristiano, los humanistas admitieron el interés de sociedades ajenas, pasando su curiosidad del pasado antiguo al presente exótico. No es verdad que el respetuoso conocimiento del otro haya nacido en nuestros días, ni tampoco que sea eterno como el hombre: en algún punto se ha producido la 'ruptura' del etnocentrismo con que las sociedades nacen, a modo de cordón umbilical que les defiende del exterior. Por eso es tan universal el etnocentrismo, y tan excepcional su ruptura: Rowe mostró que los cristianos reformadores del renacimiento requirieron el carácter modélico de la antigüedad clásica (como conjunto de modelos literarios y retóricos, pero también de saber natural y virtudes morales y cívicas) para reforzar sus críticas al cristianismo tradicional: el monopolizado por las órdenes religiosas (en el caso de Erasmo) y por la corte papal (en el caso de los florentinos como Petrarca y Boccaccio).

\section{José de Acosta, humanista}

Pero, si nos asomamos a las explicaciones suyas $-\mathrm{y}$, como veremos, al ejemplo vivo del P. Acosta- este humanismo compartido por jesuitas cumplía también metas antropológicas al estilo de las enunciadas por Rowe y Lévi-Strauss. Oigamos la explicación ejemplar del P. Dainville (1954: passim 126-156), cuando argumenta sobre el papel cumplido en los colegios jesuitas por los cursos de Historia y Geografía en términos de abrirles a la cultura clásica los ojos a los estudiantes (cuyos apuntes de clase analiza). Y, a través de ella, a las culturas del Nuevo Mundo y a

puede pensarse a sí misma si no dispone de algunas otras que sirvan de término de comparación» (L.-S., 1979, p. 257). En ocasión parecida, para defender el latín en la Secundaria, escribió M. de Unamuno un ensayo (1894: "La enseñanza del latín en España») que concluía del mismo modo: «No conoce ni su propia lengua quien sólo ella conoce. El hombre no reflexiona en lo propio sino al ponerlo en parangón con lo ajeno» (Unamuno, 1966, p. 876). la adquisición de una imagen antropológica de la humanidad:

L'histoire s'apprenait par la lecture des historiens classiques [Tite Live, Suétone, Salluste, Cesar ...] (...) Plus que de moralia ou des ethica, c'est de la fréquentation des historiens qui venait aux adolescents des colleges l'intelligence et le goút de la sagesse gréco-romaine (...) Ainsi conçue la lecture des historiens, plus féconde a tout prendre que l'étude d'un manuel, apprenait en meme temps que des faits mémorables du passé, la maniere d' écrire l'histoire et de faire réflexion sur les choses humaines [...] Le professeur éxposait les notions d'histoire, d'antiquité, de mythologie, nécessaires a l'intelligence du sujet [...] Il ne se bomait pas a décrire l'oikoumene des Anciens. [...]

S'agit-il del'Afrique? (...) Traite-t-on de I'Asie? (...) Au tête de ces amples commentaires où l'histoire a beaucoup plus de part que la géographie, de très court appendices narrent brievement la récente découverte des terres neuves, de l'Amérique et de la Magellanique et les décrivent très sommairement [...] L'expérience, echo des rélations des voyageurs ou des missions, se glissait déjà peu a peu a travers les érudits commentaires pour controuver les Anciens. Professée par des humanistes, la Géographie se préocupa comme l'Histoire du "commun humain'. Ce qui frappe le plus les hommes de ce temps dans les peuples neufs, c'est leur ressemblance avec euxmemes. Ils sont des hommes comme eux. À les connaitre, ils se sentent plus hommes».

Tengamos en cuenta este sentido particular del humanismo jesuita, donde se recibe una enseńanza de los clásicos muy poco escolástica -es decir, no en forma de tratado explícito acerca de la cultura grecolatina, 'reduciendo' ésta a la propia tradición cristiana y planteando problemas ajenos al caso- sino más bien al estilo humanista: es decir, en contacto directo con los textos clásicos, y haciendo "glosas» permanentes que obligan a usar la experiencia exótica presente en esclarecer el pasado clásico, y viceversa. Los jesuitas tuvieron problemas sistemáticos con otras órdenes, en especial con la Orden de predicadores, más ligada al Santo Oficio de la Inquisición en España: existe incluso un dictamen oficial de 1588 contrario a la Ratio studiorum o plan de estudios jesuita, porque «alaba las lenguas demasiadamente» (López Rueda, 1973: 272).

En una época, llena de prohibiciones para tratar en lengua vulgar de temas bíblicos e idolátricos, Acosta se permite muchas licencias en su historia indiana: 
está llena de traducciones bíblicas a lengua vulgar, y he podido comprobar que nada tienen que ver con la Vulgata. Como botón de muestra, véase cómo traduce Acosta los versículos 12-21 del cap. 14 del Libro de la Sabiduría; concretamente el 14.18: "Acrecentó esta invención de idolatría [con los difuntos] la curiosidad de excelentes artífices, que con su arte hicieron estas imágenes y estatuas tan elegantes, que los que no sabían lo que era les provocaban adorarlas». La edición católica española Nácar-Colunga (1953) ofrece una traducción muy diferente, que ni siquiera permite entender el sentido correcto: «Y progresando la supertición, también a los ignorantes los indujo el deseo de honrar al artista». En cuanto al P. Acosta, parece no solamente haber hecho la traducción personalmente, sino cotejando otras versiones que la Vulgata. Ello se deduce de otro caso de cita bíblica, tratada más específicamente, en el cap. 15 del libro I («De la profecía de Abdías, que algunos declaran de estas Indias»), donde recurre a las traducciones recientes de Fr. Luis de León, a la de la Vulgata, a la de los hebreos e incluso de los antiguos rabinos, advirtiendo que es un párrafo bíblico en que disienten los diversos autores, por lo que termina «dejando esta disputa, que toca a pericia de lenguas...».

Lo cierto es que Acosta emite opiniones personales harto ilustrativas de su humanismo linguístico y antropológico. Por ejemplo, en un capítulo de su tratado misional de 1588 (IV: 9, "Los misioneros que vienen a las Indias aprendan con todo cuidado el idioma de los indios») en que compara la dificultad de las lenguas indígenas de América y de Europa antigua, confiesa incluso que prefiere el mérito de sus cofrades que saben lenguas indianas sobre el teológico, que él domina: «En más tengo yo tan laudable esfuerzo y trabajo que toda la gloria de los estudios teológicos» ${ }^{16}$ (cursivas mías). Es evidente que el autor de estas palabras reclama un respeto a las lenguas indígenas, y por ello mismo se permite en el mismo tratado alguna dura crítica a quienes, misioneros o no, quieren obligar a los naturales americanos a hablar la lengua espańola: "¿en qué cabeza cabe que innumerables gentes tengan que olvidar la lengua de sus padres en su propia patria y

16 Por su interés humanístico, reproduzco el latin en que expresa esta idea: Hunc ego tam gloríosam laborem et contentionem omni theologici studi laudi antepono. Según L. Pereña (1987: 72), Acosta se refiere al P. Barzana, a quien Acosta alude también indirectamente como buen teólogo, que le acompańó hacia 1577 a su visita a la zona aymara. usar sólo de un idioma extranjero que oyen raras veces y muy a disgusto?» (IV: 8, cursivas mías).

A lo largo de su Historia indiana se emplean permanentemente los nombres indígenas de cada cosa que se alude: si algo caracteriza esta crónica (mucho más que a otras crónicas humanistas semejantes como Oviedo, Mártir, Gómara, Zárate o Cieza) es el empleo sistemático del nombre indígena, ya se trate de minerales o plantas o animales, ya se ocupe de los dioses o ritos o instituciones políticas del Nuevo Mundo. Y algo más, consideró oportuno como apéndice de su Historia natural y moral de la Indias (HNMI) reproducir el códice Tovar, es decir la relación literal de su propia historia y ritos de los indios de Tezcoco, Tula y México, tomada por su cofrade jesuita Juan de Tovar de sus ancianos mismos. De ese modo, pudo conocer Europa a tiempo - no varios siglos después, como en tantos casos - algo de las investigaciones inéditas llevadas a cabo en sus días por gentes como Fr. B. de Sahagún o Fr. Diego Durán.

Como última apoyatura del conocimiento jesuita de las lenguas y culturas indígenas, y del valor concedido a las mismas en su evangelización, merece la pena aludir a un hecho aparentemente desconectado, y es la amplitud que tuvo la Compañía para admitir en sus filas a sacerdotes mestizos, a pesar de las críticas contemporáneas. El P. Acosta se distinguió en este punto, como muestra su respuesta a un interrogatorio llevado a cabo casi al término de su estancia en Indias, hacia 1583: «a este testigo le parece cosa muy conveniente y conforme a razón que no se cierre la puerta tan absolutamente a los que con estudios e virtud puedan merecer sacerdocio, e con él, mediante la habilidad y lengua que tienen, harán mucho fruto entre los indios» (Lavallé, 1985, cursivas nuestras). Naturalmente, los mestizos como Blas Valera o el Inca Garcilaso le respondieron apoyando su gestión, y reclamando ellos mismos un respeto cultural de parte de los cristianos por su lengua. Se recordará que el P. Acosta hacía esa misma reclamación en el proemio al lector de su historia indiana, criticando a los anteriores historiadores por su ignorancia acerca de los indios, "por no saber su lengua». Pues bien, el Inca va un poco más allá, e introduce al comienzo de sus obra unas "Advertencias acerca de la lengua general de los indios del Perú", en la cual reconoce explícitamente el mérito del estudio jesuita en medio de la general desestimación: «que cierto es lástima que se pierda o corrompa, siendo una lengua tan galana, en la cual 
han trabajado mucho los Padres de la Compañia de Jesús, como las demás religiones, para saberla bien hablar» (cursivas nuestras).

\section{Evolucionismo y naturalismo de Acosta en el estudio de las sociedades.}

Después de mostrar el humanismo del P. Acosta, conviene aplicarlo a su contribución etnológica. Partiré de la interpretación del profesor Rowe (1964), por haber usado una teoría de evolución social para explicar las diferencias culturales entre pueblos contemporáneos:

Acosta proposed to classify all «barbarians» into three classes: first, those who have the knowledge and use of letters and hence posses a high degree of civility, like the Chinese and Japanese; second, those who lack writing but have an organized government and religion and live in stable setlements, like the Mexicans and Peruvians; and third, those whom he classified as savages, like the Caribs and the Brazilians (...) This is a general ethnological classification related to specific contemporary peoples. It is organized explicitly as a hierarchy of excellence with the people most like the Christian Europeans at the top and the one judged least like them at the bottom (...) Acosta's scheme is so similar in principle and even in some of its details to Lewis H. Morgan's famous scheme of 1877 that it seems almost unbelieble that there where three centuries between them» (]. H. Rowe, 1964: 8).

Aunque el Proemio a su tratado misional, de donde procede esta clasificación etnológica, había sido valorado ya como fundamento de una metodología evangélica diferenciada en función de los pueblos receptores —especialmente por jesuitas orientalistas, como Henri Bernard-Maître (1954) — sin embargo es Rowe quien ha tratado más sistemáticamente el tema de su significación taxonómico-cultural, al menos dentro del gremio antropológico. Personalmente, he reconocido ya otras veces la deuda que tengo contraída con este trabajo de Rowe (Del Pino, 1976, 1978, 1985...). Pero, debo reconocer también que lo encuentro internamente contradictorio, y desde luego en franca incompatibilidad con su otro trabajo de 1965, más conocido por otra parte. Por eso no estoy totalmente de acuerdo con algunas frases de ese trabajo original de1964, que me parecen contradictorias con su trabajo de 1965 (que era su introducción, aunque publicado posteriormente):

The Renaissance attitude [fifteenth century] was incompatible with a theory of progress (...) It is particularly important to note that the categories of the classification did not arise from detailed comparisons of ethnographic data but were derived from European popular conceptions into which Acosta fitted the meager data that he had (...) which were selected to fit the theory, on speculation, and ethnocentric value judgment (Rowe, 1964: 7 y 9. Cursivas mías).

Creo que Rowe no reconoce la conexión estrecha que hay entre Renacimiento y teoría del progreso (o entre la versión renacentista de los siglos XV y la del XVI, es decir, respectivamente imitativa o crítica del pasado) como reconoce sus diferencias dialécticas. Dos cosas diferentes y opuestas no siempre están desconectadas, y la teoría del progreso del s. Xvi puede ser hija, si bien incómoda, del afán de imitación de los antiguos. Porque no es casual que los primeros autores que postulan una teoría del progreso - como el propio Acosta - tengan una buena formación clasicista. Por otro lado, en este trabajo de 1964 también se establece una oposición entre filosofía social y etnología (que aparece subrayada en cursiva por mí en una cita anterior, 1964: 9), a las cuales ha definido anteriormente como dos tradiciones separadas hasta la segunda mitad del s. xIx: la de la filosofía social nace de la obra de Platón y Aristóteles, y consiste en reflexiones sobre la vida social y humana «by a logical argument which took for granted the values of Greek culture and the kinds of institutions with which the Greeks were familiar (...) broadened only to the extent that the historical experience of Europe was taken into account, and Christian values were combined with classical ones»(1964: 4). A esta propuesta de Rowe respondía Elliott en 1972 — sin mencionarlo- que ambas tradiciones con que se enfrenta el Viejo al Nuevo Mundo - la clásica y la cristiana - habían resultado suficientemente flexibles para asimilar las novedades sin romper la estructura propia.

Rowe sistiene que la filosofía social, como tal, no se había interesado por los datos de la otra tradición, la etnológica — la que nace con la reunión moderna de datos sobre las Indias orientales y occidentalesy ponía el ejemplo exclusivo de Jean Bodin, que reducía su interés a los pueblos europeos, modernos y clásicos, y explicaba las diferencias culturales en 
base a diferencias climáticas. Y, aunque reconocía que la tradición etnológica sí había recibido influencia de la filosófica, la centraba realmente en cosas más bien negativas: conceptos etnocéntricos como los de salvaje, bárbaro, pagano o civilizado, que más bien habían impedido comprender las nuevas sociedades en sus propios términos. Para empezar, yo dudo que estos conceptos negativos hayan tenido que esperar a la tradición clásica para divulgarse: al contrario, creo que - como todo etnocentrismo - anidan originalmente en toda comunidad. Pero es más que dudoso que todo lo que ha recibido la tradición etnológica de la otra tradición filosófica sean estos conceptos negativos, o - en concreto- que la teoría del progreso mismo no tenga que ver con la tradición clásica y con los humanistas. Por último, creo que es difícil sostener que todos los filósofos sociales a partir de 1492 hasta la segunda mitad del XIX hayan sido insensibles a los datos de procedencia etnológica, a menos que - a fortiori-se llame "filósofo social» solamente a los que prescinden de toda influencia etnológica... En este sentido, la extendida influencia de Acosta en los 'filósofos sociales' europeos del XVI-XVIII (aún por probar del todo, pero con muchos indicios en autores como W. Robertson y otros pertenecientes a la escuela de historia natural y moral) muestra lo contrario ${ }^{17}$.

Ahora bien, por encima de todas estas dudas razonables, debo confesar que tanta desconfianza sobre el 'mestizaje' ocurrido entre ambas tradiciones resulta del todo contradictorio con las afirmaciones del propio Rowe (1965) que citamos páginas atrás: a propósito del valor anti-etnocéntrico de la tradición clasicista, al ser recibida por los europeos del s. Xv. Y en esta tradición naturalmente entra muy en primer lugar Aristóteles — padre de la filosofía social, según Rowe-, de quien el P. Acosta es deudor muy consciente. Aristóteles puede ser una autoridad en física y cosmografía contestada sistemáticamente por el $\mathrm{P}$. Acosta pero, también por ello mismo, absolutamente necesaria como referencia de sus nuevas propuestas: éstas dejan de tener sentido sin aquel referente, ya que el Nuevo Mundo es «nuevo» porque no obedece a las leyes del Viejo, cuyas leyes deben ser definidas previamente de un modo categórico

17 Ver un simposio sobre el tema organizado por nosotros, y recogido en las Actas del Simposio 32 «El género americano de las 'historias naturales y morales': un modelo cognoscitivo de la diversidad cultural desde el mundo latino", Leoncio López-Ocón, Fermín del Pino, y Rafael Chabrán (Coordinadores). XXI Congreso Internacional de Historia de la Ciencia, celebrado del 8 al 14 de julio 2001, en Ciudad de México. CDroom, pp. 2901-3058. para hacer la comparación. ¡Sin Aristóteles no hay finalmente mundo «nuevo»! De ahí que el P. Acosta confiese: «no me determino a contradecir a Aristóteles si no es cosa muy cierta» (HNMI, II: 12).

Aparentemente, esta dependencia aristotélica no tiene tanta importancia por lo que hace a la Etnografía, dado que se trata de sociedades nuevas desconocidas por el viejo filósofo. Pero, y ésta es la razón de su poderosa influencia, Aristóteles propuso un método de estudio "naturalista» (es decir válido para las cosas no humanas) que podía aplicarse a las cosas humanas, y de esta homología epistemológica salen varios resultados importantes. En primer lugar una consideración "lógica» sobre el funcionamiento del mundo, que permite pensar en una racionalidad general y, por tanto, en una capacidad de comprensión de las mismas por un ser humano. Desde el comienzo del 'Proemio al lector', da a entender Acosta que merece la pena - aunque no se haya hecho todavía - comprender todo lo propio del Nuevo Mundo (natural y humano) ya que tiene su propia lógica, accesible a cualquier filósofo interesado:

Del Nuevo Mundo e Indias Occidentales han escrito muchos autores diversos libros y relaciones, en que dan noticia de las cosas nuevas y extrañas, que en aquellas partes se han descubierto (...) Mas hasta ahora no he visto autor que trate de declarar las causas y razón de tales novedades y extrañezas de naturaleza (...) A la verdad, ambas cosas tienen dificultad no pequeña (Cursivas mías)

Es cierto que el libro de Acosta resulta el más ordenado y aristotélico de todos, pues va repasando el Nuevo Mundo «cerniendo» en forma evolutiva todas las noticias que posee en el tamiz aristotélico de elementos simples (aire, agua, tierra, y fuego) y compuestos (minerales, plantas y animales), y de sociedades americanas (religión, sociedad, y etnohistoria de las dos sociedades más evolucionadas de América: incas y aztecas). Partiendo de que todos los seres se componen de los mismos elementos, y que en todos los mundos hay los mismos compuestos, el más noble de los cuales es el hombre, el orden descriptivo que debe adoptar resulta una especie de "necesidad lógica", como él mismo reclama al comienzo de los capítulos de «historia moral»:

Habiendo tratado lo que a la historia natural de Indias pertenece, en lo que resta se tratará de la 
historia moral, esto es de las costumbres y hechos de los indios. Porque después del cielo y temple, y sitio y cualidades del Nuevo Orbe, y de los elementos y mixtos — quiero decir, de sus metales, y plantas y animales - de que en los cuatro libros precedentes se ha dicho lo que se ha ofrecido, la razón dicta seguirse el tratar de los hombres que habitan el Nuevo Orbe (Prólogo a los libros siguientes, cursivas mías).

Este orden razonable del relato se apoya en una jerarquía natural de los seres, y en una cadena evolutiva que los une a todos, que ubica al hombre en una relación «natural» con el resto de la creación. Esto se aprecia en la HNMI de Acosta de un modo casi inconsciente, dándolo por hecho - y por supuesto no citando a Aristóteles-, aunque en alguna esquina puede advertirse el sistema, como cuando justifica el orden en que se relatan los "compuestos», al inicio del libro IV:

(...) y aunque hay muchos otros géneros, a tres reduciremos esta materia, que son metales, plantas y animales. Los metales son como plantas encubiertas en la tierra (...) así también podemos decir que las plantas son como animales fijos en un lugar, cuya vida se gobierna del alimento que la naturaleza les provee en su propio nacimiento. Mas los animales exceden a las plantas, que como tienen ser más perfecto, tienen necesidad de alimento también: más perfecto y para buscalle les dió la naturaleza movimiento y, para conocerle y descubrirle sentido. De suerte que la tierra estéril y ruda es como materia y alimento de los metales; la tierra fértil y de más sazón es materia y alimento de plantas; las mismas plantas son alimentos de animales, y las plantas y animales alimento de los hombres, sirviendo siempre la naturaleza inferior para sustento de la superior y la menos perfecta subordinándose a la más perfecta. De donde se entiende cuán lejos está el oro y la plata y los demás, que los hombres ciegos de codicia estiman en tanto, de ser fin digno del hombre, pues están tantos grados más abajo que el hombre, y sólo al Creador y universal Hacedor de todo está sujeto y ordenado el hombre... (1590, IV: 1)

Estas razones «naturales» — tanto que todosla entienden, incluso los no cristianos - son en realidad parte de un sistema filosófico que se impuso modernamente en la Contrareforma, pero que procedía de Aristóteles, como nos lo explica un autor de nuestros días hablando del naturalismo ilustrado:
(...) dos ideas de la ciencia aristotélica -muy diferentemente elaboradas $y$, en verdad, bastante laxamente conectadas entre sí- fueron recibidas como legado por la historia natural del Renacimiento. Una era la idea de la jerarquía de los seres (...) La otra era el postulado de que las transiciones entre las cosas naturales son imperceptibles y casi continuas" (Arthur O. Lovejoy 1983, pp. 91-93, citando a otro autor anterior, H. Daudin 1926, De Linné à Jussieu).

La jerarquía de los seres, unidos por una cadena interna de servicio recíproco, no dejaba de aplicarse a las mismas sociedades como sistemas integrados «naturalmente»: aplicado a las diferentes sociedades conocidas, esto tenía una inmediata repercusión etnológica que es la enfatizada por J. H. Rowe, al hablar del sistema evolucionista de Acosta. Así que la teoría del progreso de las culturas tiene, a pesar de Rowe, una presencia en el Renacimiento, precisamente a través de Aristóteles.

$\mathrm{Si}$ se repasa el esquema histórico de Acosta se comprueba esta fe jesuita en el destino civilizatorio de todos los pueblos americanos, si se les deja solos. Para hacer esta historia, a veces Acosta acude a tradiciones locales americanas, llegando a recoger literalmente la mexicana. Al contrario de lo que planteaba Rowe, el interés 'etnológico' de Acosta no reside en que sea capaz de "modelar» la evolución de las sociedades americanas a la luz de las filosofías y prejuicios vulgares europeos - ie., el etnocentrismo- sino al contrario, que propone una ley universal de evolución de todas las culturas justamente a partir de las tradiciones orales incaicas y aztecas — pero se sobreentiende que vale para todas las sociedades precristianas-, y de ello hay varios ejemplos. Y ello ocurre justamente donde señalaba Rowe que planteaba Acosta una clasificación cultural, con una secuencia evolutiva que "did not arise from detailed comparisons of ethnographical data but were derived from European popular conceptions» (Rowe, 1964: 9): es decir en el cap. 25 del libro. Allí comienza Acosta reflexionando «a partir de datos indígenas, re-interpretados»

Hay conjeturas muy claras que por gran tiempo no tuvieron estos hombres reyes ni repúblicas concertada, sino que vivían por behetrías [derivado de 'benefactorías': sociedades en libertad de elegir el señor que quieren], como ahora los floridos y chiriguanos, y los brasiles y otras naciones muchas, que no tienen ciertos reyes, sino que conforme a la ocasión que se ofrece en guerra o paz eligen sus 
caudillos como se les antoja. Mas con el tiempo, algunos hombres que en fuerzas y habilidad se aventajaban a los demás, comenzaron a señorear y mandar, como antiguamente Nembrot (Génesis, 10:8), y poco a poco creciendo vinieron a fundar los reinos de Perú y Méjico, que nuestros españoles hallaron que, aunque eran bárbaros, pero hacían grandísima ventaja a los demás. Asi que la dicha razón persuade que se haya multiplicado y procedido el linaje de los indios por la mayor parte de hombres salvajes y fugitivos (cursivas mías).

Como dice Rowe, parece que se trata de prejuicios populares europeos, o al menos «prejuicios» propios de la cultura europea, apoyándose en ejemplos de la Biblia como el cazador Nembrot, que se alzó a rey por sus méritos. Pero Acosta nos da también ejemplos concretos de pueblos americanos, que viven en el presente. Más aún, en los libros de historia moral (V-VII) hay al menos dos capítulos que tratan «Del origen de los ingas, señores del Perú...» (HNMI, VI:19), y «De los antiguos moradores de la Nueva España...", donde queda claro si esta versión la tomó Acosta de prejuicios europeos o, más bien, de tradiciones americanas. En el caso peruano, la cosa queda bastante clara, porque se trata de investigaciones explícitas, las realizadas por Sarmiento de Gamboa entrevistando incas ancianos de Cuzco:

Por mandado de la Majestad Católica del rey D. Felipe, nuestro señor, se hizo averiguación con la diligencia que fue posible del origen y ritos y fueros de los incas, y por no tener aquellos indios escrituras no se pudo apurar tanto como se deseara. Mas por sus quipos y registros, que como está dicho les sirven de libros, se averiguó lo que aquí diré. Primeramente en el tiempo antiguo en el Perú no había reino ni señor a quien todos obedeciesen; mas eran behetrías y comunidades, como lo es hoy día el reino de Chile, y ha sido cuasi todo lo que han conquistado los espańoles en aqueIlas Indias Occidentales, salvo el reino de México, para lo cual es de saber que se han hallado tres géneros de gobierno y vida en los indios... (VI: 19).

En el caso de México se vuelve a decir lo mismo, pero con alguna apoyatura mayor en nombres, y con un esfuerzo más evidente de generalización a otros pueblos: porque se cuenta aún con mayores medios escritos de conservarse una versión indígena de su historia, pues sabemos que Acosta recogió allí el códice de su cofrade Juan de Tovar, y lo publicó como libro VII, justamente donde está la cita a que aludimos. Dice así en el capítulo antes mencionado (HNMI, VII: 2):

Los antiguos y primeros moradores de las provincias que llamamos Nueva España fueron hombres muy bárbaros y silvestres, que solamente se mantenían de caza, y por eso le pusieron nombre de 'chichimecas' (...) Quieren decir que de estos mismos eran los que en la Nueva España llaman 'otomíes', que comúnmente son indios pobres y poblados en tierra áspera, pero están poblados y viven juntos, y tienen alguna policía (...) estos chichimecas y otomíes de quienes se ha dicho que eran los primeros moradores de la Nueva Espańa, como no cogían ni sembraban, dejaron la mejor tierra y más fértil sin poblarla, y ésa ocuparon las naciones que vinieron de fuera, que por ser gente política llaman 'nahuatlata': que quiere decir gente que se explica y habla claro, a diferencia de esa otra bárbara y sin razón.

Pero, no conforme con esa tradición indígena mexicana transmitida en códices, y apoyada en nombres y en razones de jerarquía cultural, se atreve en el capítulo siguiente a proponer una 'ley general' de la evolución que no parece tan desprovista de fundamento etnográfico como apunta Rowe:

Los bárbaros chichimecos, viendo lo que pasaba, comenzaron a tener alguna policía, y cubrir sus carnes (...) y ya hacían sus chozas y bohíos, y teman algún orden de república, eligiendo sus señores y reconociéndoles superioridad c...) Por este mismo tenor tengo por cierto que han procedido las más naciones y provincias de Indias (...) Asi fue en México, asi fue en el Perú, y asi es sin duda donde quiera que se hallan ciudades y repúblicas fundadas entre estos bárbaros (HNMI, VII:3. Cursivas mías).

Es evidente que estos misioneros supieron escuchar tradiciones dinásticas y prejuicios etnocéntricos americanos no muy diferentes de los greco-latinos (nabuatlato $=$ político, $\mathrm{y}$ chichimeca $=$ bárbaro $)$ y aprovecharlos en sus "conjeturas» históricas de pretensiones universales. Aunque es evidente, otra vez, que no habrían hecho esta utilización de no haber sido sensibilizados previamente por una manera de aprovechar la historia greco-romana para reflexionar sobre temas genéricos (religión, moral, política, civilización...) y, en definitiva, para elevar la 
contemplación de los problemas propios a la luz de esquemas más universales (Cf. Dainville, 1954, passim).

\section{Referencias bibliográficas}

Acosta, José de (1590). Historia natural y moral de las Indias. Juan de León, Sevilla. (Vid. ed. O'Gorman).

Acosta, José de (1589). De natura Novi Orbis libri duo, et De promulgatione Evangelii apud barbaros, sive de procuranda Indorum salute libri Sex. Apud Guillelmum Foquel. Salmanticae. (Vid. ed. Pereña)

Bernard-Maitre, Henry (1954). «Humanisme jesuite et humanisme de l'Orient», Analecta Gregoriana, vol. LXX: 187-192: Roma.

Dainville, François (1954). «L'enseignement de l'Histoire et de la Géographie, et la 'Ratio Studiorum»'. Analecta Gregoriana, vol. LXX: 123-156. Roma.

Darnell, Regna (1974, ed.). Readings in the history of Anthropology. Harper and Row Publ., New York.

Del Pino Díaz, Fermín (1976). "Canarias y América en la historia de la Etnología prirnigenia: usando una hipótesis». Revista de Indias, 145/146: 99-156. Madrid.

Del Pino Díaz, Fermín (1978). «Contribución del padre Acosta a la constitución de la Etnología. Su evolucionismo» Revista de Indias, n. 153/154: 507-546. Madrid.

Del Pino Díaz, Fermín (1979). «Los reinos de Méjico y Cuzco en la obra del P. Acosta». Revista de la Universidad Complutense, n. 117: 13-43. Madrid.

Del Pino Díaz, Fermín (1982). "Culturas clásicas y americanas en la obra del padre Acosta». En Francisco de Solano y Fermín del Pino (Eds.) América y la España del siglo XVI. Consejo Superior de Investigaciones Científicas, pp. 327-362. Madrid:

Del Pino Díaz, Fermín (1985). «Las fuentes españolas sobre América prehispánica corno precursoras de la Etnología europea: problemas historiográficas y científicos» En F. DEL PINO (Ed.) Ensayos de metodología histórica en el campo americanista. "Anexos de la Revista de Indias», $\mathrm{n}^{\circ}$ 1. Centro de Estudios Históricos, Madrid.

Del Pino Díaz, Fermín (1985a). «El misionero español José de Acosta y la evangelización de las Indias orientales». Missionalia Hispanica, XLII: 275-298. Madrid.

Del Pino Díaz, Fermín (1992a). «Humanismo renacentista y orígenes de la Etnología: a propósito del P. Acosta, paradigma del humanismo antropológico", en Berta Ares, Jesús Bustamante, Francisco Castilla y Fermín Del Pino (Eds.), Humanismo y visión del otro en la
España moderna: cuatro estudios, Madrid, C. S. I. C., Biblioteca de Historia de América, 6: pp. 379-429.

Del Pino Díaz, Fermín (1992b). «La Renaissance et le Nouveau Monde: José d'Acosta, jésuite anthtropologue 0540-1600)» L'Homme, XXXII: 311-328. París.

Dainville, François (1940). «L'enseignement de l'Histoire et de la Géographie, et la Ratio studiorum», Analecta Gregoriana, LXX, (1940) pp. 123-156. Roma.

Elliott, John H. (1972). El Viejo Mundo y el Nuevo, 14921650. Madrid: Alianza Editorial.

ElliotT, John H. (1972a). "The Discovery of America and the Discovery of Man» (Raleigh Lecture, 1972). Proceedings of theBritish Academy, 48: 101-125. London.

Elliott, John H. (1975). «Renaissance Europe and America: A blumted impact? En Fredi Chiapelli (Ed.) First Images of America. The impact of the New Worl on the Old. vol. 1, pp. 11-23. Berkeley: University of California Press.

Fernández de Oviedo, Gonzalo (1959 [1535]). Historia general y natural de las Indias. Edición y estudio preliminar de Juan Pérez de Tudela Bueso. Madrid: Biblioteca de Autores Españoles, CXVII. Ed. Atlas.

Hodgen, Margared T. (1964). Early Anthropology in the Sixteenth and Seventeenth Centuries. Philadelphia: University of Pennsylvania Press.

InCa Garcilaso de la Vega (1965 [1609]). «Comentarios reales de los incas» En Obras completas del..., vol. II. Edición y estudio preliminar del P. Carmelo Sáinz de Santamaría. Biblioteca de Autores Espańoles, 133. Madrid: Atlas.

LAVALLÉ, Bernard (1985). «La admisión de los americanos en la Compañía de Jesús: el caso de la provincia peruana en el siglo XVI». Histórica, pp. 137-153. Lima

LeVi-Strauss (1979). Antropología estructural. Mito, sociedad, humanidades. México: Siglo XXI editores.

López-Ocón, Leoncio; Fermín del Pino, y Rafael Chabrán (Coordinadores). Actas del Simposio 32 «El género americano de las 'historias naturales y morales': un modelo cognoscitivo de la diversidad cultural desde el mundo latino", XXI Congreso Internacional de Historia de la Ciencia, celebrado del 8 al 14 de julio 2001, en Ciudad de México. CDroom, pp. 2901-3058.

López Rueda, José (1973). Helenistas españoles del siglo XW. Madrid: Consejo Superior de Investigaciones Científicas.

Lovejoy, Arthur 0. (1983). La gran cadena del ser. Historia de una idea. Icaria Antrazyt: Barcelona.

LowIe, Robert H. (1946). Historia de la etnología. México: Fondo de Cultura Económica. (traducción de P. Kirchoff). 
Maravall y Casesnoves, José Antonio (1951). «Sobre naturaleza e historia en el humanismo español» Arbor, XVIII: 469-493. Madrid.

Maravall y Casesnoves, José Antonio (1966). Antiguos y modernos: la idea de progreso en el desarrollo inicial de una sociedad. Madrid: Sociedad de Estudios y Publicaciones.

Momigliano, Arnaldo (1960). "The place of Herodotus in the History of Historiography" History, 43: 1-13 (También en sus Studies in Historiography. N. York and London, 1966).

Nacar, E. y Colunga, A. (1953). Sagrada Biblia. Versión directa de las lenguas originales, por ...5ta. edición. Madrid: Biblioteca de Autores Cristianos.

Pagden, Anthony (1988). La caida del hombre natural. El indio americano y los orígenes de la etnología comparativa. Madrid: Alianza Editorial.

Pereña, Luciano et alii (1984/1987, ed.). José de Acosta. De procuranda Indorum salute.Colección Corpus
Hispanorum de Pace, vols. XXIII-XXIV. Madrid: Consejo Superior de Investigaciones Científicas.

Rowe, John H. (1964). «Ethnography and Ethnology in the Sixteenth Century». Kroeber Anthropological Society Papers, 30: 1-15. Berkeley.

Rowe, John H. (1965). The Renaissance Foundations of Anthropology. American Anthropologist, 67: 1-20. Menasha.

Rowe, John H. (1974). «Sixteenth and Seventeenth Centuries Grammars" En DELL HYMES (Ed.) Studies in the History of Linguistics. Traditions and Paradigms. Indiana U. P., London and Bloomington.

Unamuno, Miguel de (1966 [1894]). «La enseñanza del latín en España». En Obras completas... Tomo I. Paisajes y Ensayos, pp. 875-889. Madrid: Talleres Gráficos Escelicer S.A. 